\title{
Emotional Stress Induces Structural Plasticity in Bergmann Glial Cells via an AC5-CPEB3-GluA1 Pathway
}

\author{
Crhistian Luis Bender, ${ }^{1,4 *}{ }^{\odot}$ Xingxing Sun, ${ }^{1,5,6 *}$ Muhammad Farooq, ${ }^{1,6}$ Qian Yang, ${ }^{1}$ Caroline Davison, ${ }^{1}$ \\ Matthieu Maroteaux, ${ }^{1}{ }^{-}$Yi-shuian Huang, ${ }^{2}$ Yoshihiro Ishikawa, ${ }^{3}$ and Siqiong June Liu ${ }^{1,6}$ \\ ${ }^{1}$ Department of Cell Biology and Anatomy, LSU Health Sciences Center, New Orleans, Louisiana 70112, ${ }^{2}$ Institute of Biomedical Sciences, Academia \\ Sinica, Taipei 115, Taiwan, ${ }^{3}$ Cardiovascular Research Institute, Yokohama City University Graduate School of Medicine, Yokohama 232-0024, \\ Japan, ${ }^{4}$ Instituto de Farmacología Experimental de Córdoba-CONICET, Departamento de Farmacología, Facultad de Ciencias Químicas, Universidad \\ Nacional de Córdoba, Córdoba X5000GYA, Argentina, ${ }^{5}$ Department of Anesthesiology, Tongji Hospital, Tongji Medical College, Huazhong \\ University of Science \& Technology, Wuhan 430030, People's Republic of China, and ${ }^{6}$ Southeast Louisiana VA Healthcare System, New Orleans, \\ Louisiana 70119
}

Stress alters brain function by modifying the structure and function of neurons and astrocytes. The fine processes of astrocytes are critical for the clearance of neurotransmitters during synaptic transmission. Thus, experience-dependent remodeling of glial processes is anticipated to alter the output of neural circuits. However, the molecular mechanisms that underlie glial structural plasticity are not known. Here we show that a single exposure of male and female mice to an acute stress produced a long-lasting retraction of the lateral processes of cerebellar Bergmann glial cells. These cells express the GluAl subunit of AMPA-type glutamate receptors, and GluA1 knockdown is known to shorten the length of glial processes. We found that stress reduced the level of GluA1 protein and AMPA receptor-mediated currents in Bergmann glial cells, and these effects were absent in mice devoid of CPEB3, a protein that binds to GluA1 mRNA and regulates GluA1 protein synthesis. Administration of a $\beta$-adrenergic receptor blocker attenuated the reduction in GluAl, and deletion of adenylate cyclase 5 prevented GluA1 suppression. Therefore, stress suppresses GluA1 protein synthesis via an adrenergic/adenylyl cyclase/CPEB3 pathway, and reduces the length of astrocyte lateral processes. Our results identify a novel mechanism for GluA1 subunit plasticity in non-neuronal cells and suggest a previously unappreciated role for AMPA receptors in stress-induced astrocytic remodeling.

Key words: adrenergic receptors; astrocytic remodeling; Bergmann glial cells; CPEB3; glial processes; GluA1

Significance Statement

Astrocytes play important roles in synaptic transmission by extending fine processes around synapses. In this study, we showed that a single exposure to an acute stress triggered a retraction of lateral/fine processes in mouse cerebellar astrocytes. These astrocytes express GluA1, a glutamate receptor subunit known to lengthen astrocyte processes. We showed that astrocytic structural changes are associated with a reduction of GluA1 protein levels. This requires activation of $\beta$-adrenergic receptors and is triggered by noradrenaline released during stress. We identified adenylyl cyclase 5 , an enzyme that elevates cAMP levels, as a downstream effector and found that lowering GluA1 levels depends on CPEB3 proteins that bind to GluA1 mRNA. Therefore, stress regulates GluA1 protein synthesis via an adrenergic/adenylyl cyclase/CPEB3 pathway in astrocytes and remodels their fine processes.

\section{Introduction}

Stress modifies the structure and function of neurons and glial cells in the brain, producing lasting changes in behavior and physiology. This is significant because the experience of traumatic events can lead to neuropsychiatric disorders (McEwen and Gianaros, 2010; Franklin et al., 2012) including anxiety, depression, and drug addiction (Shin and Liberzon, 2010; Edwards et al., 2013; Papp et al., 2014). While it is established that stress can alter spine density, dendritic length, and complexity in neurons 
(Christoffel et al., 2011; Davidson and McEwen, 2012), astrocytes, which are a critical component of synaptic transmission, can also undergo structural changes. The fine processes of astrocytes contact presynaptic and postsynaptic sites, where glutamate transporters in astrocytes rapidly remove glutamate released from presynaptic terminals (Araque et al., 1999). It is therefore not surprising that they are essential for stress-related behavior. For example, astrocyte ablation in the prefrontal cortex gives rise to depression-like behaviors, and chronic stress reduces the number of astrocytes and their main branches (Banasr and Duman, 2008; Tynan et al., 2013). Given the importance of astrocyte processes in neurotransmitter clearance, their retraction is expected to prolong the presence of glutamate at the synaptic site and enhance transmission. However, how stress remodels the structure of astrocytes is still poorly understood (Bender et al., 2016).

Exposure of rodents to natural predator odors causes innate fear (Takahashi et al., 2005; Staples, 2010), and the cerebellum is involved in the processing of the fear response to predators as lesions of the cerebellar vermis reduce a freezing response in rats exposed to a cat (Supple et al., 1987). There are extensive connections between the cerebellum and brain regions that are important for defense responses, including the limbic, prefrontal cortex, and sympathetic nervous systems (Bostan et al., 2013). Exposure to predator odor evokes norepinephrine release from the locus ceruleus, and we have previously shown that this increases GluA2 transcription in cerebellar stellate cells and enhances feedforward inhibition (Liu et al., 2010; Savtchouk and Liu, 2011). The cerebellum is also critical for the consolidation of associative fear conditioning (Fischer et al., 2000; Sacchetti et al., 2002; Timmann et al., 2010). Therefore, a stress-induced change in synaptic transmission in the cerebellum may alter the processing of emotion and fear memory.

Bergmann glial (BG) cells in the cerebellum have lateral, fine processes surrounding both excitatory and inhibitory synapses in the molecular layer and regulate synaptic transmission (Ango et al., 2008; De Zeeuw and Hoogland, 2015). Retraction of these processes can lead to motor deficits (Saab et al., 2012). Because stress is a common trigger for cerebellar ataxia (Jen, 2000), we examined whether stress altered the size of the glial processes. These astrocytes express a high level of GluAl subunits that form $\mathrm{Ca}^{2+}$-permeable AMPA receptors. Selective expression of GluA2 and knockdown of the GluA1 subunit in Bergmann glial cells reduces the length of their processes and impairs motor coordination (Iino et al., 2001; Saab et al., 2012). Thus, the ability of emotional stress to regulate GluA1 expression in astrocytes suggests a mechanism for controlling the length of Bergmann glial processes.

Our results show that a single exposure to predator odor produces a lasting reduction in the length of Bergmann glial lateral processes and a decrease in GluA1 expression and AMPA receptor-mediated currents in glial cells. We found that deletion of CPEB3 (cytoplasmic polyadenylation element binding protein 3 ), a protein that binds to GluAl mRNA, prevented the suppression of GluA1 protein levels and a decrease in the current via AMPA receptors, suggesting that stress reduces GluA1 protein synthesis in Bergmann glial cells. Blocking $\beta$-adrenergic receptors during emotional stress attenuates the reduction in GluA1 levels, and deletion of adenylyl cyclase 5 (AC5) abolishes the

The authors declare no competing financial interests.

Correspondence should be addressed to Siqiong June Liu at sliu@lsuhsc.edu.

https://doi.org/10.1523/JNEUROSCI.0013-19.2020

Copyright $\odot 2020$ the authors change in GluA1 expression. Therefore, acute stress suppresses GluA1 expression via activation of a $\beta$-adrenergic receptor-AC5 pathway that requires CPEB3. Our results reveal a new form of GluA1 subunit plasticity in astrocytes and suggests a novel role for AMPA receptors in stress-induced astrocytic remodeling.

\section{Materials and Methods}

\section{Animals}

We used 5- to 8-week-old C57BL/6J NPY::GFP mice (stock \#006417, The Jackson Laboratory) for the morphologic analysis of Bergmann glial cells because GFP is expressed in scattered BG cells in this mouse line. FVB/NJ GFAP::GFP mice (stock \#003257, The Jackson Laboratory) were used for the analysis of GluA1 immunoreactivity (IR) in the molecular and Purkinje cell layers occupied by the processes and somata, respectively, of Bergmann glial cells. Adenylyl cyclase 5 (AC5) knockout $(\mathrm{KO})$ mice, $\mathrm{C} 57 \mathrm{BL} / 6 \mathrm{~J}$ CPEB3 $\mathrm{KO}$ mice, and their wild-type (WT) controls were used for immunohistochemical and electrophysiological experiments. In all experiments, both male and female animals were used. We did not observe any difference in the stress-induced change in GluA1-IR in 5- to 6-week-old $(81 \pm 2 \%)$ and 7- to 8 -week-old ( $84 \pm 1 \%)$ mice $\left(t_{(16)}=-0.6 ; p=0.56\right)$, and therefore data were pooled from these animals. All procedures were approved by the Animal Care and Use Committee of Louisiana State University Health Sciences Center.

\section{Stress paradigm}

Mice were exposed to fox urine as described previously (Liu et al., 2010). Briefly, a mouse was placed in a cage $(13 \times 9 \times 6$ inches $)$ for $2 \mathrm{~min}$. A paper towel containing fox urine $(2.5 \mathrm{ml})$ was then inserted below the raised floor, which contained small holes allowing the odor to permeate into the chamber. The animal was exposed to odor for $5 \mathrm{~min}$, then returned to their home cage and killed 3 or $24 \mathrm{~h}$ later. Care was taken to minimize handling stress. Control ("naive") animals were left undisturbed in their home cages.

\section{Pharmacological experiments}

Mice were exposed to fox urine $30 \mathrm{~min}$ after the intraperitoneal injection of saline or propranolol $(20 \mathrm{mg} / \mathrm{kg}$, dissolved in saline; injection volumes: $0.1 \mathrm{ml} / 15 \mathrm{~g}$ body weight). Home cage animals that did not receive an injection and stressed animals were littermates of same sex. Naive mice receiving a saline or propranolol injection or no injection served as additional controls. At $24 \mathrm{~h}$ after exposure to fox urine, animals were killed, then perfused with paraformaldehyde, and the brains were processed for GluA1 staining, as described below.

\section{Histology and immunohistochemistry}

NPY::GFP mice, which express GFP in Bergmann glial cells, were used to determine the length of glial processes. Animals were perfused intracardially with $10 \mathrm{ml}$ of heparinized PBS followed by 20 $\mathrm{ml}$ of $4 \%$ paraformaldehyde. The brains were postfixed overnight in paraformaldehyde, then kept in $25 \%$ sucrose in PBS. Cerebellar slices of $30 \mu \mathrm{m}$ were cut with a cryostat at $-20^{\circ} \mathrm{C}$, collected in wells containing PBS, and mounted on slides.

For immunohistochemistry, animals were intracardially perfused with $10 \mathrm{ml}$ of heparinized PBS followed by $50 \mathrm{ml}$ of $4 \%$ paraformaldehyde with a peristaltic pump $(2 \mathrm{ml} / \mathrm{min})$. The brains were postfixed overnight in paraformaldehyde solution and then kept in PBS at $4^{\circ} \mathrm{C}$. Cerebellar slices of $50 \mu \mathrm{m}$ were obtained using a vibratome. Free-floating sections were preincubated in blocking/permeabilization solution (PBS containing $5 \%$ BSA and $0.1 \%$ Triton $\mathrm{X}-100$ ) for $2 \mathrm{~h}$ at room temperature. The slices were then incubated with primary antibodies overnight. After five washes in PBS (10 min each), the sections were incubated with secondary antibodies for $2 \mathrm{~h}$ at room temperature, then were washed five times and mounted on slides. Slides were dried, and sections were mounted in Vectashield. Antibodies were diluted in PBS that contained $1 \%$ BSA and $2 \%$ donkey serum. To detect CPEB3-IR, antigen retrieval was conducted in $10 \mathrm{~mm}$ sodium citrate solution, $\mathrm{pH} 6$, at $95^{\circ} \mathrm{C}$ for 
30 min. Sections were washed twice in PBS then followed by the standard immunostaining procedure.

The following primary antibodies were used: rabbit anti GluA1 (1:1000; catalog \#AB1504 1, Chemicon); mouse anti-CPEB3 (1:200; Chao et al., 2013); rabbit anti-GFAP (1:500; DAKO); chicken anti-GFP (1:500; Santa Cruz Biotechnology); and rabbit anti-AC 5/6 (1:500; catalog \#sc-590, Santa Cruz Biotechnology). The following secondary antibodies were used: $\mathrm{Cy} 3$ donkey anti-mouse (1:400; The Jackson Laboratory); Invitrogen Alexa Fluor 488 goat anti-chicken (1:400; Thermo Fisher Scientific); Invitrogen Alexa Fluor 488 donkey anti-rabbit (1:400; Thermo Fisher Scientific), Cy3 donkey anti-rabbit (1:400; The Jackson Laboratory); and Invitrogen Alexa Fluor 488 goat anti-mouse (1:400; Thermo Fisher Scientific).

\section{Image acquisition and analysis}

Morphologic analysis of Bergmann glial cells

Images of GFP fluorescence were acquired with a TCS SP2 SE Leica confocal microscope at $63 \times$ plus $2 \times$ camera optical zoom, a step size of $0.5 \mu \mathrm{m}$ and $1024 \times 1024$ pixel resolution. The final thickness of each stack varied between 18 and $25 \mu \mathrm{m}$. In NPY::GFP mice, a subset of Bergmann glial cells expresses GFP, and their scattered distribution allows for individual cells to be photographed for analysis of lateral processes. From each animal, at least three cells in lobule 5 of the cerebellar vermis were photographed. The lengths of 40 lateral processes arising from the main glial branches were measured from each image, and the average length of 120 processes from three images was calculated for each animal. Seven to eight mice were used for each experimental condition.

For lateral process length analysis, a 3-D reconstruction was made using Leica software (Leica Microsystems Heidelberg 1997-2004). Rotation of the image facilitated the differentiation of the main processes (usually three to five main branches) from their respective lateral processes. The length of any single, clearly identifiable, lateral process that emanated from the principal process was manually traced and quantified using ImageJ with the aid of a pair of 3-D glasses. Lateral processes that contained smaller processes giving a final brush-like appearance were not considered in this analysis because of their complexity and heterogeneity. The brush-like pattern was more prominent in the superficial third of the molecular layer (proximal to the surface and distant from the somatic layer), hence most of the measurements were conducted in the inner two-thirds of the molecular layer. The samples were coded, and the analysis was conducted blind to the experimental conditions.

To confirm that our manual measurement of glial process length was random and nonbiased, we assessed the morphologic changes using skeleton analysis. The same image stacks used for 3-D reconstruction were used to create single maximum projected images that were subject to visual thresholding and then skeletonization with ImageJ software. The skeleton analysis plug-in was applied to obtain the length of all branches found in the skeleton (Arganda-Carreras et al., 2010). No pruning algorithm was applied, but we discarded all processes that were $<1 \mu \mathrm{m}$ and $>10 \mu \mathrm{m}$, which was the size range of the processes obtained with the free-hand manual measurements. The drawback of this approach is that projection of a 3-D image onto a $2-\mathrm{D}$ plane would reduce the length of processes that are outside of the projection plane. Indeed, the average length of the process in both control conditions and after stress were smaller overall than in the manual measurement protocol and the number of processes was higher. However, the relative change in the length of processes after stress was the same as found using the manual measurement approach. The Pearson correlation coefficient between the average length of glial processes from each animal using manual measurements and skeleton analysis was $0.72(p<0.0001)$. A good match between both methods validates our manual measurements as a nonbiased approach. Because skeleton analysis underestimates the lengths of glial processes, the manual measure was used in our study.

\section{Immunoreactivity analysis and quantification}

GluA1 images were acquired with an epifluorescence microscope (Nikon Eclipse TE2000-U) at 10× magnification. Lobules 5 and 9 from the cerebellar cortex were analyzed from at least five sections per animal. The sections selected for analysis were matched with sagittal diagrams
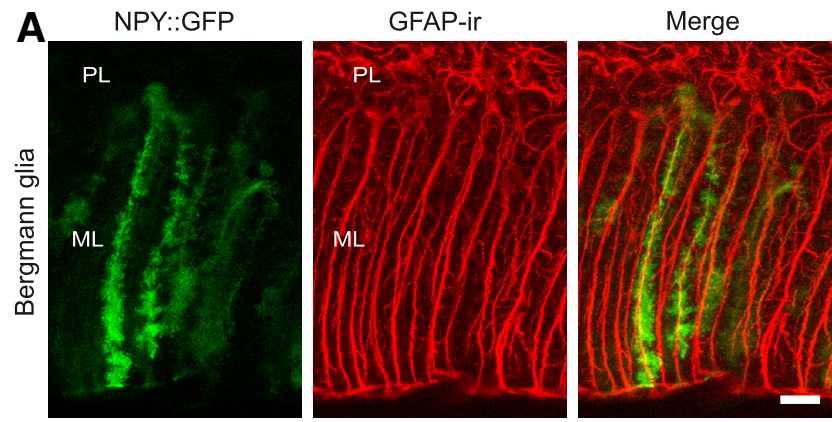

B

Naive

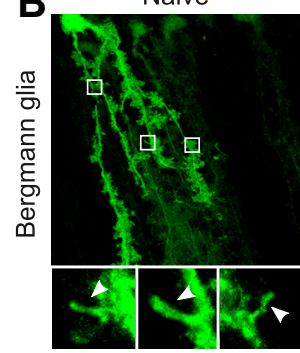

$3 \mathrm{hrs}$ after stress

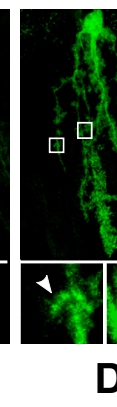

C

D

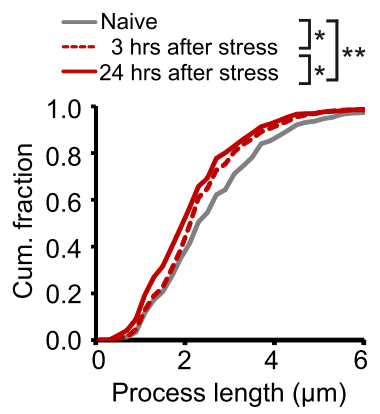

Stress $\underset{24 \mathrm{hrs}}{\stackrel{3 \mathrm{hrs}}{\longrightarrow}}-$-Morphological analysis -Immunohistochemistry

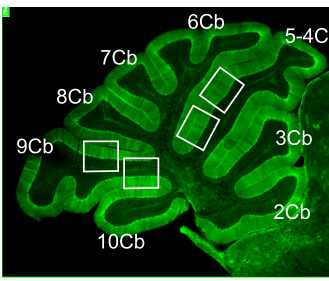

Figure 1. Bergmann glial cell lateral processes are shorter after stress. $\boldsymbol{A}$, Confocal images showing that NPY::GFP mice exhibit fluorescent labeling of a subset of GFAP-positive Bergmann glial cells. $\boldsymbol{B}$, Retraction of the lateral processes of Bergmann glial cells was evident $3 \mathrm{~h}$ after exposure to fox urine, and the effect became more pronounced at $24 \mathrm{~h}$. Top panels show whole-cell images, and each was made from a z-projection of all 25-30 confocal slices. Inserts illustrate z-projections of two to three consecutive confocal slices to reveal individual processes. C, Cumulative distribution of the length of lateral processes in Bergmann glial cells from naive mice, and at 3 and $24 \mathrm{~h}$ after stress exposure (836-914 processes from 22-24 cells/each condition; $N=7$ ). $\boldsymbol{D}$, Top, Schematic representation of the experimental design. Bottom, Sagittal section of the cerebellum from a GFAP::GFP mouse showing the lobules and areas analyzed in this study (lobules 5 and 9). ML, Molecular layer; $\mathrm{PL}$, Purkinje cell layer. Scale bar, $20 \mu \mathrm{m}$. ${ }^{*} p<0.0001$; ${ }^{* *} p<0.000001$ (KolmogorovSmirnov test).

located between 0.12 and 0.36 lateral to the midline in the mouse atlas by Paxinos and Franklin (2001; Fig. 1D). The mean intensity of staining in the molecular, granule, and Purkinje cell layers was quantified using ImageJ. Because GluA1 is expressed in Bergmann glial cells but not in granule cells, GluA1-immunoreactivity in the granule cell layer was considered as background and was subtracted from the values obtained in the molecular layer, where the processes of BG are found, and from the Purkinje cell layer where the BG soma are located. The divisions between the Purkinje cell layer and molecular or granule cell layer were guided using the GFAP::GFP signal present in the BG somata. In each figure, the symbols indicate the mean value from each animal. Identical symbols are used for the same sex littermate control and stressed animals from each independent experiment. GluA1-IR was normalized to the average value of the naive control from the same batch of animals to account for the variability in staining intensity between different batches of animals. To determine whether immunostaining of GluA1 and CPEB3 was colocalized with GFAP-IR or GFP in GFAP::GFP mice, confocal images 
were acquired using a TCS SP2 SE confocal microscope $(63 \times$ objective; Leica). Maximum projected images were produced from a stack of images at a step size of $0.5 \mu \mathrm{m}$ (resolution, $1024 \times 1024)$ and used for analysis.

\section{Electrophysiological recordings}

Cerebellar slices were prepared from 25- to 35-d-old naive mice or mice that were exposed to fox urine $24 \mathrm{~h}$ previously, as described previously (Savtchouk and Liu, 2011). Briefly, horizontal slices $(300 \mu \mathrm{m})$ were cut from the cerebellar vermis using a vibratome (VT1200, Leica) in an icecold solution containing the following $(\mathrm{mM})$ : $\mathrm{CaCl}_{2}(0.5), \mathrm{NaCl}(81.2)$, $\mathrm{KCl}$ (2.4), $\mathrm{NaHCO}_{3}$ (23.4), $\mathrm{NaH}_{2} \mathrm{PO}_{4}$ (1.4), $6.7 \mathrm{MgCl}_{2}$ (6.7), glucose (23.3), sucrose (69.9), and gassed with carbogen $\left(95 \% \mathrm{O}_{2} / 5 \% \mathrm{CO}_{2}\right)$. Slices were then transferred to aCSF solution containing the following (mM): $\mathrm{NaCl}$ (125), $\mathrm{KCl}$ (2.5), $\mathrm{NaHCO}_{3}$ (26), $\mathrm{NaH}_{2} \mathrm{PO}_{4}$ (1.25), $\mathrm{MgCl}_{2}$ (1), $\mathrm{CaCl}_{2}$ (2), glucose (25), and saturated with $95 \% \mathrm{O}_{2}, 5 \% \mathrm{CO}_{2}$ at room temperature for at least $30 \mathrm{~min}$ before recording. Recording pipettes (4$7 \mathrm{M} \Omega$ ) were pulled from borosilicate capillary glass (GC150F-7.5, Harvard Apparatus; with a PP-830 puller, Narishige) and were filled with the following potassium-based internal solution ( $\mathrm{mM}): \mathrm{MgCl}_{2}(2)$, HEPES (10), $\mathrm{CH}_{3} \mathrm{KO}_{3} \mathrm{~S}$ (140), EGTA (0.5), and Na-ATP(2). The stimulation pipettes were fabricated from thin-wall borosilicate capillary glass (GC150TF-10, Harvard Apparatus) and filled with aCSF.

Bergman glial cells were identified by the size and location of somata in the Purkinje cell layer, and a hyperpolarized resting membrane potential (approximately $-80 \mathrm{mV}$ ) immediately after obtaining the whole-cell patch-clamp configuration. Whole-cell voltage-clamp recordings were obtained from cerebellar Bergmann glial cells in lobule $5 / 6$, at $-80 \mathrm{mV}$, using a Multiclamp 700A (Molecular Devices), and currents were filtered at $10 \mathrm{kHz}$ and digitized at $20 \mathrm{kHz}$. Parallel fibers were stimulated using a thin-wall pipette positioned within the molecular layer $(20-30 \mathrm{~V}, 200 \mu \mathrm{s}$ pulse), and membrane currents in Bergman cells were recorded in response to stimuli. Series resistance compensation $(\geq 60 \%)$ was applied to minimize voltage errors during recordings. A non-NMDAR inhibitor (10 $\mu \mathrm{M}$ NBQX) was applied through the perfusion system after a $5 \mathrm{~min}$ stable baseline recording. Data acquisition and analysis were performed using pClamp 9.0 (Molecular Devices). Series resistance, input resistance, and cell capacitance were monitored throughout the recording, and these were discarded if the parameters changed by $>20 \%$.

\section{Statistics}

The Kolmogorov-Smirnov (K-S) test was used for analyzing the cumulative distribution of the length of Bergmann glial cell processes. We used a two-tailed unpaired Student's $t$ test to compare normalized GluA1-IR in littermates (naive vs stress) that were processed in parallel and to compare the stress-induced change in GluA1-IR between two genotypes or pharmacological treatment groups. We analyzed the effect of stress on GluA1 expression by normalizing GluA1-IR in naive and stressed mice either to the batch average of naive GluA1-IR or to the average GluA1-IR within each pair [stressed and naive littermates; = $\left(\right.$ GluA1-IR naive + GluA1-IR $\left.\left.\mathrm{I}_{\text {stressed }}\right) / 2\right]$. Statistical analysis of these two sets of data using unpaired Student's $t$ test were comparable, and we therefore present only the GluA1-IR result normalized to the batch average of naive GluA1-IR in Figures 2 and 3 (and see also Figures 5 and 8). Only normalized GluA1-IR values in stressed mice are reported in the text of the Results section. A repeated-measures ANOVA was used to compare the intensity of GluA1-IR among different lobules. An unpaired $t$ test was used for comparison of AMPA receptor-mediated currents in naive mice and after stress. Data are presented as the mean \pm SEM, and the $n$ value is the number of animals unless otherwise indicated. Data were considered to be significantly different at $p<0.05$.

\section{Results}

Acute stress reduces the length of Bergmann glial cell lateral processes

The cerebellum is critical for both motor coordination and nonmotor functions, with different cerebellar lobules being involved
A

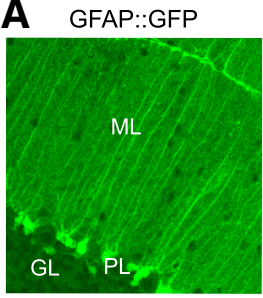

B

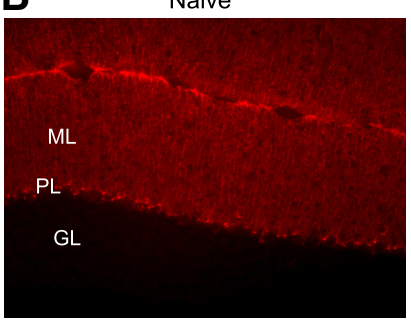

Processes
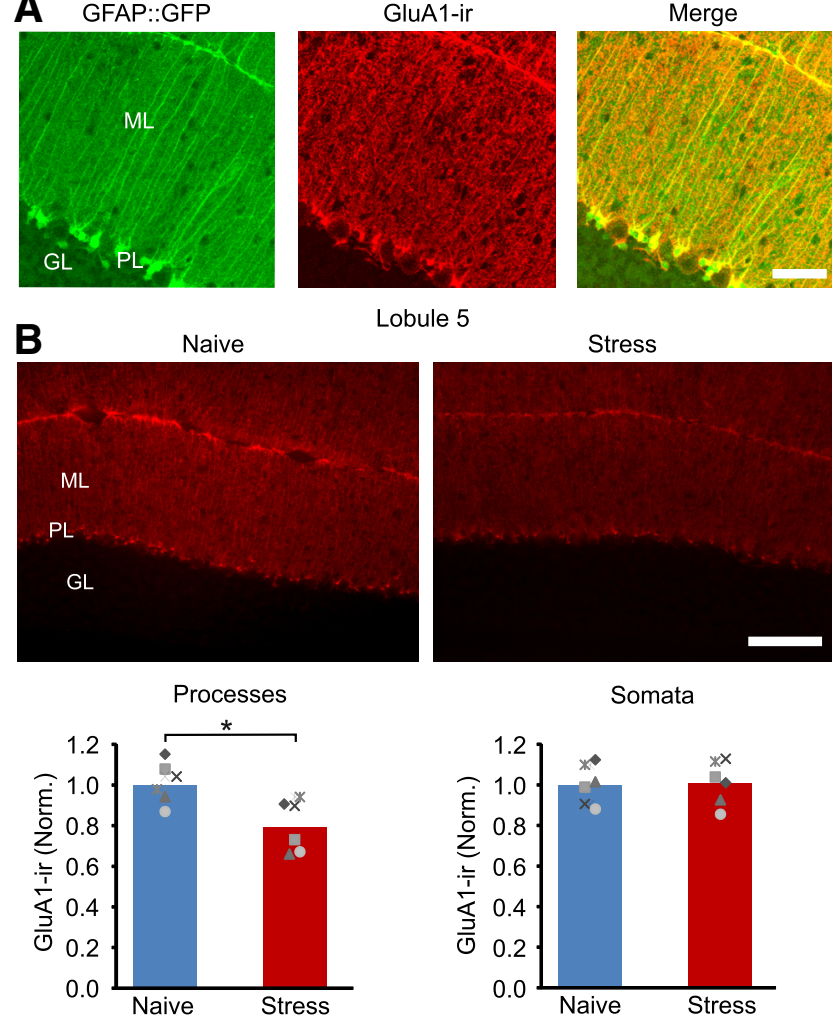

Lobule 5

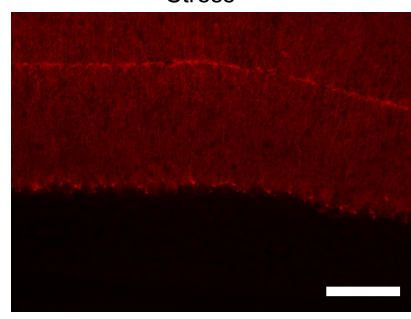

Somata
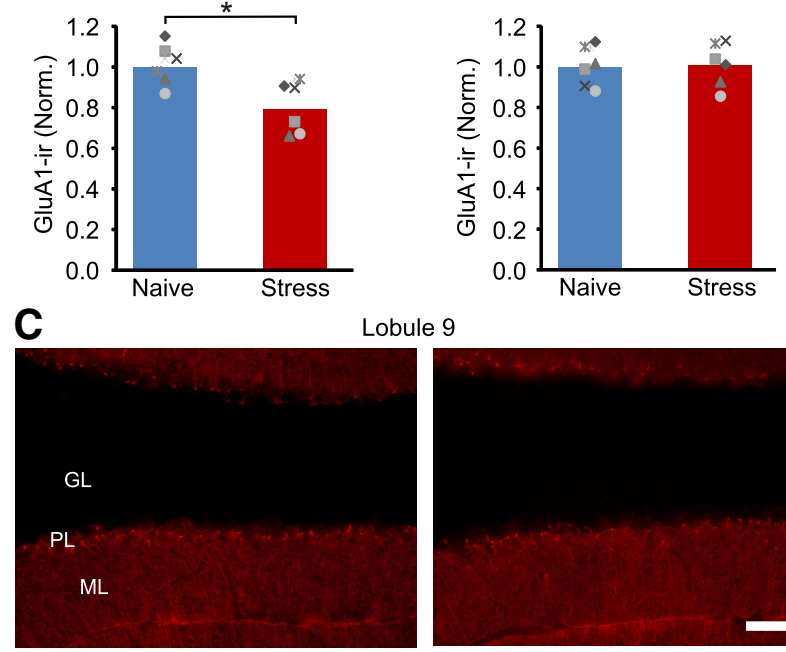

Processes
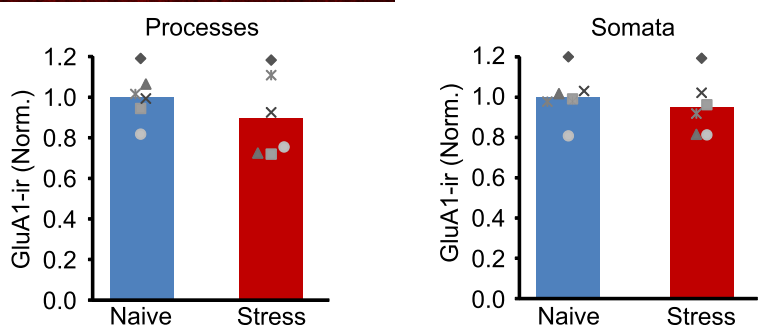

Figure 2. Stress reduces GluA1 expression in Bergmann glial cell processes in cerebellar lobule 5. $\boldsymbol{A}$, Confocal images of cerebellar cortex stained for the GluA1 AMPA receptor subunit in GFAP::GFP mice shows that GluA1 is highly expressed in Bergmann glial cells. $\boldsymbol{B}$, Top, Epifluorescence GluA1-IR images of lobule 5 in a naive control mice and after stress. Bottom, The mean intensity of GluA1-IR in Bergmann cell processes (in the molecular layer of the cerebellar cortex) and the somata of Bergmann cells (located in the Purkinje cell layer) in lobule 5. Stress reduced the level of GluA1-IR in the molecular layer (naive, $N=6$; stress, $N=6$ ). $C$, Top, GluA1-IR images of lobule 9. Bottom, Mean GluA1-IR in Bergmann processes and somata in cerebellar lobule 9. ML, Molecular layer; $\mathrm{GL}$, granule cell layer; PL, Purkinje cell layer; ns, not significant. Scale bars: $\boldsymbol{A}, 50 \mu \mathrm{m} ; \boldsymbol{B}, 100 \mu \mathrm{m} .{ }^{*} p<0.02$ (unpaired $t$ test).

in distinct behaviors. The formation of fear memory requires the activity of cerebellar vermal lobule 5, and motor learning involves lobules 9/10 (Sacchetti et al., 2002, 2004; Ruediger et al., 2011). Because stress can enhance subsequent fear learning and memory (Perusini et al., 2016), we examined whether exposure to predator odor altered the length of Bergmann glial cell 
processes in lobule 5 , a region that is critically involved in fear memory consolidation.

BG cells have two to four primary processes, from which fine processes then extend laterally and form close contacts with both excitatory and inhibitory synapses in the molecular layer of the cerebellum. To measure the length of the lateral branches emanating from the main processes, we took advantage of a transgenic NPY::GFP mouse line in which GFP is selectively expressed in scattered BG cells within the cerebellar cortex (Fig. 1A). This enabled us to perform single-cell 3 -D reconstructions and to recognize and quantify the length of individual lateral processes.

To determine whether acute stress altered the size of the glial processes, NPY::GFP mice were exposed to fox urine for $5 \mathrm{~min}$ and cerebella were fixed 3 or $24 \mathrm{~h}$ later. In naive mice, the average length of BG lateral processes in lobule 5 was $2.80 \pm 0.22 \mu \mathrm{m}(n=8)$. In contrast, the length of processes in mice that were exposed to predator odor stress was reduced to $2.4 \pm 0.14 \mu \mathrm{m}(n=7)$, when evaluated $3 \mathrm{~h}$ after exposure (Fig. $1 B, C$ ). The distribution of the size of an individual process showed that stressed animals had shorter lateral processes than naive controls (Fig. $1 C$; naive: 24 cells and 891 processes; 3 h after stress: 22 cells and 914 processes; $\mathrm{K}-\mathrm{S}$ test: naive vs $3 \mathrm{~h}$ after stress; $p<0.0001)$. At $24 \mathrm{~h}$ after stress, the length of the lateral processes was further reduced to $2.26 \pm 0.08 \mu \mathrm{m}$ ( $n=7$; Fig. $1 B, C ; 24$ h after stress: 22 cells and 836 processes; vs naive; K-S test, $p<0.000001$ ), compared with $3 \mathrm{~h}$ after stress (K-S test, $p<0.0001$ ). Thus, a single emotional stress was able to induce a sustained retraction of glial processes that lasted for at least $24 \mathrm{~h}$, a form of structural plasticity in cerebellar astrocytes.

\section{GluA1 expression in Bergmann glial cells decreases after acute emotional stress}

Bergmann glial cells express high levels of GluA1 subunits that form $\mathrm{Ca}^{2+}$-permeable AMPA receptors. Knockdown of GluA1 and overexpression of GluA2 in BG cells decreases the expression of $\mathrm{Ca}^{2+}$-permeable AMPA receptors and reduces the length of the lateral processes (Iino et al., 2001; Saab et al., 2012). We hypothesized that the shortening of lateral processes after stress could result from a downregulation of GluA1 expression. Using immunohistochemistry, we detected GluA1-IR in the cerebellar cortex, where GluA1 is almost exclusively expressed in BG cells (Petralia and Wenthold, 1992). We found that GluA1 immunostaining in GFAP::GFP mice was localized to GFP-positive processes and BG somata, with little staining of stellate cells and a low level of GluA1-IR in the soma of Purkinje cells, and no staining above background in the granule cell layer (Fig. 2A), as previously reported (Petralia and Wenthold, 1992; Baude et al., 1994).

We next quantified the level of GluA1-IR in the molecular layer since the processes of BG cells extend from the Purkinje cell layer, through the molecular layer, and terminate as end-feet on the surface of the cerebellar cortex (Figs. 1B, 2B). Compared with naive controls, the average GluA1 immunoreactivity in the molecular layer of lobule 5 decreased by $21 \%$ in mice $24 \mathrm{~h}$ after fox urine exposure (stress, $0.79 \pm 0.13$; unpaired $t$ test: $t_{(10)}=$ $-3.12, p<0.011$ ), indicating a reduction in GluA1 protein after stress. This change occurred selectively in the molecular layer in
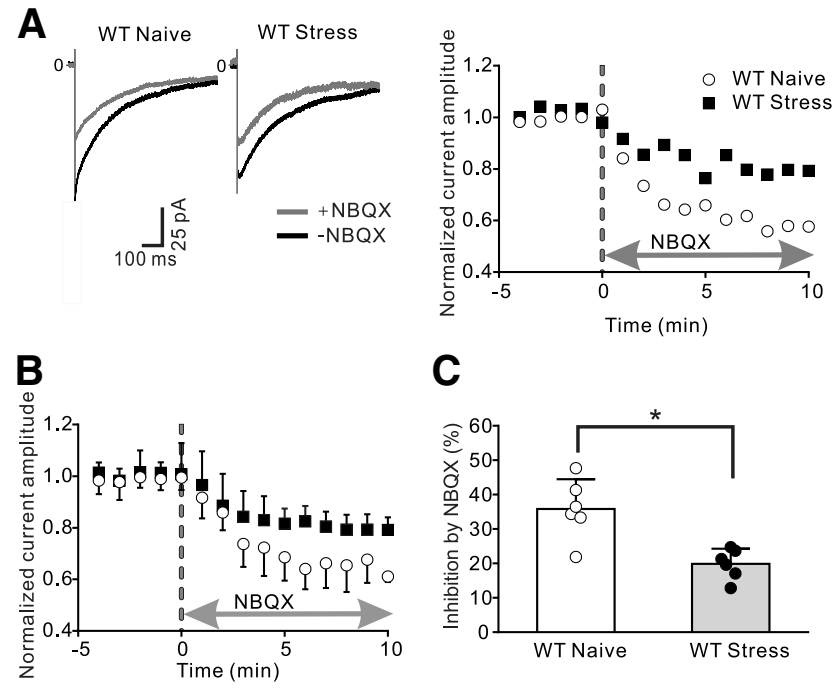

Figure 4. Exposure to predator odor decreased AMPAR-mediated currents in Bergmann glial cells. Cerebellar slices were prepared from the vermis of naive animals or stressed mice (24 $\mathrm{h}$ after fox urine exposure). Stimulation of parallel fibers evoked an inward current in Bergmann glial cells located in cerebellar lobule 5. Application of NBQX (10 $\mu \mathrm{m})$ inhibits AMPA receptor-mediated currents. $\boldsymbol{A}$, Example current traces in the presence and absence of NBQX (left) and corresponding time course of the evoked AMPAR-mediated current amplitude (right). $\boldsymbol{B}$, Summary data of the change in current amplitude over time (naive, $N=6$; stress, $N=6)$. $C$, Average current ratio $\left(=I_{\mathrm{NBQX}} / I_{\text {total }}\right)$ shows a decrease after stress relative to control. ${ }^{*} p<0.005$ (unpaired $t$ test).

lobule 5 because no difference was observed in the BG somatic layer (stress, $1.01 \pm 0.11$; unpaired $t$ test: $t_{(10)}=-0.17, p=0.871$ ) or the molecular layer in lobule 9 (stress, $0.90 \pm 0.2$; unpaired $t$ test: $t_{(10)}=1.05, p=0.319$; Fig. $2 C$ ). Furthermore, stress did not alter GFP expression in the molecular layer in lobule 5 (stress, $0.92 \pm 0.1$; unpaired $t$ test: $t_{(6)}=1.40, p=0.210$ ).

Exposure to fox urine reduced the length of Bergmann glial cell lateral processes, and this was detected as early as $3 \mathrm{~h}$ after stress (Fig. 1). We therefore determined the level of GluA1-IR 3 $\mathrm{h}$ following stress in C57BL/6J mice. We found that GluA1-immunoreactivity in the molecular layer of lobule 5 was reduced by $16 \%$ (stress, $0.84 \pm 0.11$; unpaired $t$ test: $t_{(6)}=2.68, p=0.036$ ), but not in lobule 9 (Fig. $3 A-C$ ). The decrease in GluA1 expression 
A
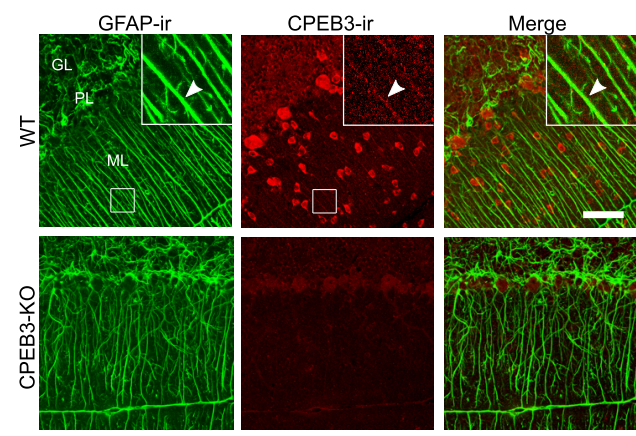
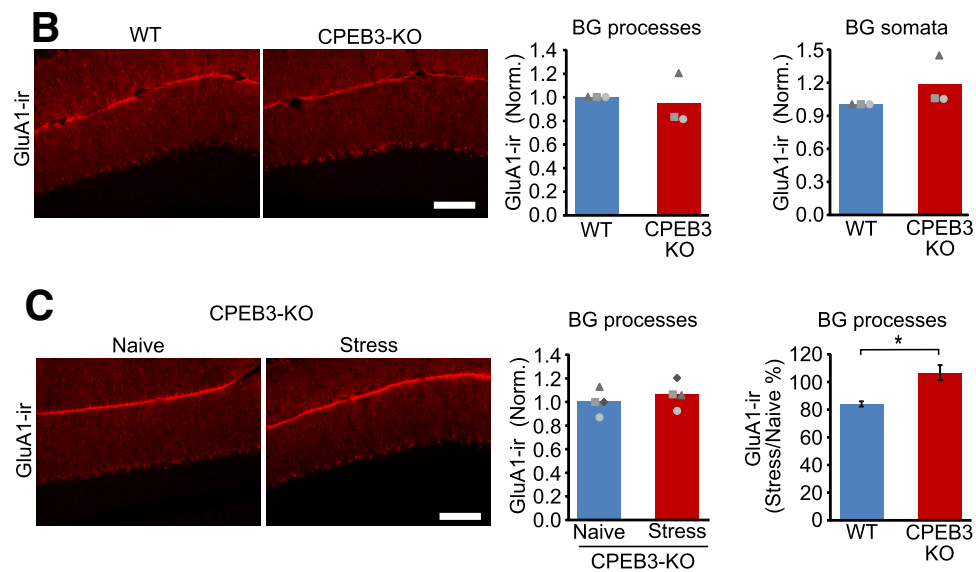

Figure 5. Deletion of CPEB3 prevents the stress-induced reduction in GluA1 expression in Bergmann glial cells. $\boldsymbol{A}$, Confocal images of GFAP-IR and CPEB3-IR indicate that CPEB3 is expressed in Bergmann glial cell processes (top right corner) as well as in granule cells and molecular layer interneurons. CPEB3-IR was absent in CPEB3 knock-out mice. $\boldsymbol{B}$, Epifluorescence images, and the corresponding quantification of GluA1-IR in wild-type and CPEB3 KO mice, indicates that there is no difference between genotypes (WT, $N=3 ; K 0, N=3$ ). C, Epifluorescence images and GluA1-IR in naive $\mathrm{KO}$ and stressed KO mice. Deletion of CPEB3 did not alter GluA1-IR in the molecular layer (naive KO, N=4; stress K0, $N=4$ ). Stress reduced GluA1-IR by $16 \pm 4 \%$ in wild-type mice (naive WT, $N=3$; stress $W T, N=3$ ). ML, Molecular layer; GL, granule cell layer; PL, Purkinje cell layer. Scale bars: $\boldsymbol{A}, 50 \mu \mathrm{m} ; \boldsymbol{B}, \boldsymbol{C}, 100 \mu \mathrm{m}$. ${ }^{*} p<0.02$ (unpaired $t$ test).

$\left(=100 \%\right.$ * $\left(\right.$ GluA $\left.\left.1-\mathrm{IR}_{\text {stress }}\right) / \mathrm{GluA} 1-\mathrm{IR}_{\text {naive }}\right)$ persisted as the level of GluA1-IR remained suppressed $24 \mathrm{~h}$ after fox urine exposure (percentage of change at 3 vs $24 \mathrm{~h}$; unpaired $t$ test: $t_{(8)}=-0.67$, $p=0.519$; Fig. $3 D$ ). Therefore, predator odor stress induced a rapid and sustained decease in GluA1 expression.

As a second independent approach, we tested whether stress altered AMPA receptor-mediated currents in Bergmann glial cells from C57BL/6J mice. Stimulation of parallel fibers evokes the release of glutamate, and activates AMPA receptors and glutamate transporter activity in these cells, producing an inward current (Clark and Barbour, 1997). We made whole-cell patch-clamp recordings from Bergmann glial cells in vermal lobule 5 and detected an inward membrane current immediately following parallel fiber activation (Fig. 4A). To isolate the component of this current that was mediated via AMPA receptors, we applied NBQX, a non-NMDA receptor blocker, and found that the current amplitude was rapidly reduced reaching a plateau after 5$10 \mathrm{~min}$. From these experiments, we conclude that AMPA receptors mediate $\sim 35 \%$ of the parallel fiber-evoked current in Bergmann cells from naive mice, consistent with a previous report (Clark and Barbour, 1997). To determine the effects of stress on this current, we exposed mice to fox urine, and prepared cerebellar slices the next day and quantified the parallel fiber stimulationevoked currents. In this condition, the application of NBQX blocked $19.9 \%$ of the inward current in Bergmann cells, a markedly smaller inhibition compared with naive controls (unpaired $t$ test: $t_{(10)}=4.030, p=0.0024$; Fig. $\left.4 B, C\right)$. This reduced inhibition by NBQX indicates a decrease in AMPA receptor-mediated current in these astrocytes after acute stress. Therefore, predator odor stress lowered the expression level of GluA1 protein and reduced the amplitude of the AMPA receptor-mediated current in Bergmann glial cells.

\section{Deletion of CPEB3 prevents the stress- induced reduction in GluA1 expression in Bergmann glial cells}

The synthesis of GluA1 is regulated by an RNA binding protein, CPEB3, that suppresses the translation of GluA1 (Chao et al., 2013; Drisaldi et al., 2015). Thus, stress may reduce GluA1 protein levels via a CPEB3-dependent pathway in Bergmann glial cells. We observed CPEB3-IR in Bergmann glial-like processes and in interneurons in the molecular layer, and this staining was abolished in CPEB3 knock-out mice (Fig. 5A). Double immunolabeling with GFAP and CPEB3 antibodies showed a colocalization of CPEB3-IR with GFAP-IR (Fig. 5A). Thus, Bergmann glial cells express the CPEB3 protein.

We next determined whether CPEB3 regulated GluA1 expression during stress. CPEB3 knock-out mice were exposed to predator odor, and the GluA1 expression level in the cerebellar cortex was quantified $24 \mathrm{~h}$ later. The intensity of GluA1 staining in the molecular layer in lobule 5 in naive CPEB3 knock-out mice was not different from that in wild-type littermates $\left(\mathrm{GluA1}_{\mathrm{CPEB} 3-\mathrm{KO}} / \mathrm{GluA}_{\mathrm{WT}}\right.$ : $0.95 \pm 0.22$; unpaired $t$ test: $t_{(2)}=0.4, p=0.708$; Fig. $5 B$ ). There was also no difference in the level of GluA1-IR in the somatic layer $\left(\mathrm{KO}, 1.18 \pm 0.23\right.$; unpaired $t$ test: $t_{(2)}$ $=-1.40, p=0.234)$. However, stress no longer reduced GluA1IR in the molecular layer in CPEB3 KO mice (stressed, $1.06 \pm 0.07$; unpaired $t$ test: $t_{(6)}=-0.81, p=0.449$; Fig. $5 C$ ). No difference was found in GluA1-IR in the somatic (or Purkinje cell) layer in naive and stressed CPEB3 KO mice (stress, $0.96 \pm 0.04$; unpaired $t$ test: $t_{(6)}=1.92, p=0.103$ ). In contrast to $\mathrm{KO}$ mice, emotional stress reduced GluA1-IR in the molecular layer in lobule 5 by $16 \pm 4 \%$ (WT vs KO; unpaired $t$ test: $t_{(5)}=-3.40, p=0.019$ ) in wild-type mice (Fig. $5 C)$. These results indicate that $\mathrm{CPEB} 3$ is required for the stress-induced decrease in GluA1 expression in Bergmann glial cells.

To determine whether these effects were associated with a change in the functional expression of AMPA receptors, we stimulated parallel fibers and quantified the evoked AMPA currents in Bergmann glial cells from naive CPEB3 knock-out mice. NBQX application blocked $37.5 \%$ of the parallel fiber-evoked current (Fig. 6), which was indistinguishable from recordings in naive WT mice. Thus, deletion of CPEB3 did not alter basal AMPA receptor expression in Bergmann glial cells. We next determined whether knockout of CPEB3 prevented the stressinduced decrease in AMPAR currents in astrocytes. Mutant mice were exposed to fox urine, and the amplitude of the parallel fiber-evoked currents was determined the next day. When NBQX was applied, the inward current was reduced by $34.6 \%$, 

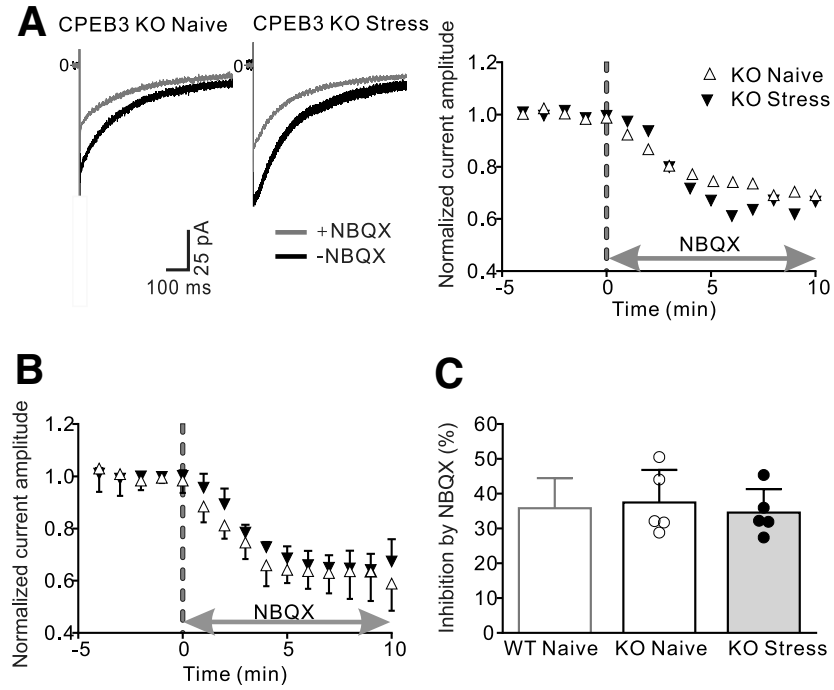

Figure 6. Stress failed to reduce AMPAR-mediated currents in Bergmann glial cells in CPEB3 K0 mice. Cerebellar slices were prepared $24 \mathrm{~h}$ after fox urine exposure or from naive CPEB3 knock-out mice. Stimulation of parallel fibers evoked an inward current in Bergmann glial cells, and the application of NBQX was used to assess the contribution of AMPARs to the total evoked current. $\boldsymbol{A}$, Example current traces (left) and corresponding time course of the change in current amplitude (right). $\boldsymbol{B}$, Summary data of current amplitude over time (naive, $N=5$; stress, $N=5)$. C, Average current ratio $\left(I_{\mathrm{NBQX}} / I_{\text {total }}\right)$ remains unaltered after stress relative to control.

and this inhibition is comparable to naive $\mathrm{KO}$ mice (unpaired $t$ test: $\left.t_{(8)}=0.56, p=0.59\right)$, indicating that stress no longer reduced AMPAR expression in Bergmann glial cells in CPEB3 KO mice. Therefore, CPEB3 is required for the stress-induced decrease in the level of GluA1 and AMPA receptors in cerebellar astrocytes following stress, but is not required for their basal expression.

\section{A $\beta$-adrenergic receptor-adenylyl cyclase 5 pathway mediates the stress-induced decrease in GluA1}

Emotional stress triggers the release of norepinephrine in the cerebellum and alters synaptic transmission between cerebellar neurons (Siggins et al., 1971; Kondo and Marty, 1998; Liu et al., 2010; Paukert et al., 2014). We used a pharmacological approach to determine whether the release of norepinephrine was involved in the stress-induced change in GluA1 expression. Age-matched littermates were divided into the following three groups: naive control; administration of propranolol ( $20 \mathrm{mg} / \mathrm{kg}$, i.p.), a $\beta$-adrenergic blocker, $30 \mathrm{~min}$ before the predator odor exposure; and saline injection $30 \mathrm{~min}$ before the predator odor exposure. As expected, GluA1-IR in lobule 5 was reduced by $26 \pm 2 \%$ following fox urine exposure (naive, $n=5$; stress, $n=5$ ). However, after propranolol administration, stress produced a smaller reduction in the levels of GluA1-IR ( $12 \pm 1 \%, n=5$; Fig. 7), compared with naive control mice (stress-induced change relative to naive control: vehicle vs propranolol, the molecular layer, unpaired $t$ test: $t_{(8)}=-4.57, p=0.002$; Bergmann glial cell somata, $t$ test: $t_{(8)}=1.07, p=0.32$; Fig. 7). Because propranolol and saline injection did not suppress GluA1 expression in naive mice (molecular layer: saline/naive $=114 \pm 10 \%$; propranolol $/$ naive $=97 \pm 13 \%$; unpaired $t$ test: $t_{(4)}=0.68739, p=0.53$; Bergmann glial layer: saline $/$ naive $=94+15 \% ; \quad$ propranolol $/$ naive $=108+18 \% ; \quad t_{(4)}=$ $-0.56609 ; p=0.60$ ), propranolol partially prevented the stressinduced decrease in GluA1 immunoreactivity. This suggests that norepinephrine released during stress activates $\beta$-adrenergic receptors, leading to a reduction in GluA1 expression in Bergmann glial cells. Because the level of GluA1-IR in stressed mice that were injected with propranolol remained lower than in that in naive controls (Fig. 7), additional signaling pathways or stress hormones may also contribute to the downregulation of GluA1 expression in Bergmann glial cells.

$\beta$-Adrenergic receptors are coupled to adenylyl cyclases, and activation of these receptors increases cAMP levels in astrocytes (Rougon et al., 1983). Therefore, stress may activate adenylyl cyclase in Bergmann glial cells and reduce GluA1 expression. We detected AC5/6-immunoreactivity in the molecular layer, and this was colocalized with GFAP-IR (Fig. 8A). Control experiments showed that AC5/6 staining was reduced in AC5 KO mice (Fig. $8 A$ ). We next tested whether deletion of AC5 prevented the stress-induced decrease in GluA1 expression. Exposure to fox urine reduced the level of GluA1-IR in lobule 5 in the molecular layer in wild-type mice (WT stress, $0.89 \pm 0.06$; unpaired $t$ test: $t_{(6)}=2.88, p=0.031$; Fig. $8 B$ ) as well as in the somatic layer (stress, $0.88 \pm 0.06$; unpaired $t$ test: $\left.t_{(6)}=2.63, p=0.036\right)$. The stress-induced decrease in GluA1-IR in both molecular and Purkinje cell layers was abolished in AC5 knockout mice (Fig. $8 C$; in the molecular layer, $\mathrm{KO}$ stress: $1.08 \pm 0.18$, unpaired $t$ test: $t_{(2)}=-0.75, p=0.494$; in the PC layer, KO stress: $\left.0.93 \pm 0.09, t_{(2)}=1.32, p=0.256\right)$. These results indicate that the stress-induced downregulation of GluA1 expression requires AC5 activation.

\section{Discussion}

AMPA receptors are found in most neurons in the CNS and mediate excitatory synaptic transmission. Neuronal activity can regulate the expression and activity of synaptic AMPA receptors (Wang et al., 2010), modifying synaptic efficacy and leading to experience-dependent changes in behavior. While the critical role of neuronal AMPARs in synaptic plasticity is well established, these receptors are also expressed in astrocytes. In the cerebellum, Bergmann glial cells express GluA1 and GluA4 subunits and thus have Ca-permeable AMPA receptors (Piet and Jahr, 2007). Genetic knockdown of GluA1 subunits or transgenic expression of GluA2 in Bergmann glial cells reduces the length of their processes (Iino et al., 2001; Saab et al., 2012). These changes lead to an impairment of motor coordination (Saab et al., 2012) and suggest that the activation of GluA1-containing AMPA receptors in astrocytes controls both their morphology and cerebellar-dependent behavioral output. Consequently, an activitydependent change in astrocyte GluA1 expression is expected to alter astrocyte morphology. In this study, we demonstrate that predator odor stress causes retraction of the lateral processes and lowers GluA1 expression in Bergmann glial cells. We further identified the underlying mechanisms and show that stress triggers norepinephrine release and activation of adrenergic receptors and AC5, and induces a CPEB3-dependent suppression of GluA1 expression.

\section{Regulation of glial GluA1 via CPEB3}

Stress can increase GluA2 gene transcription expression and potentiate GluA1 phosphorylation, and this has been shown to reduce the threshold for LTP in neurons in several brain regions (Hu et al., 2007; Liu et al., 2010; Vialou et al., 2010; Lee et al., 2013; Li et al., 2014; Perusini et al., 2016). In contrast, our results show that stress reduces GluA1 expression in astrocytes. CPEB3, a GluA1 mRNA binding protein, produces a bidirectional regulation of GluA1 protein synthesis in neurons, as mono-ubiquitination of CPEB3 enhances protein synthesis, whereas SUMOylated CPEB3 suppresses translation (Pavlopoulos et al., 2011; Drisaldi et al., 2015). Genetic deletion of CPEB3 attenuates a learning-induced 
A

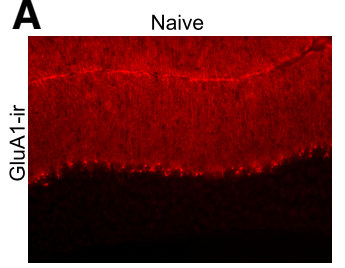

B

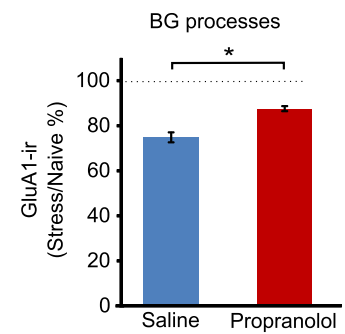

Stress + Propranolol

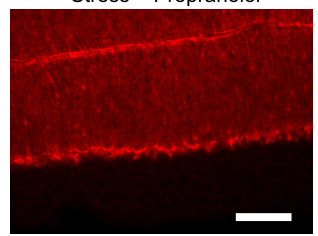

BG somata

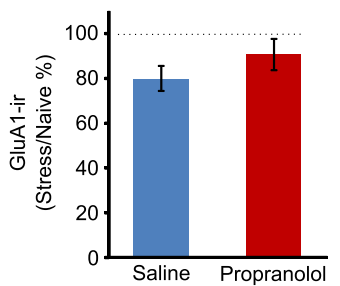

Figure 7. Stress-induced decrease in GluA1-IR is prevented by a $\beta$-adrenergic receptor antagonist. $\boldsymbol{A}$, The downregulation of GluA1-IR after stress was partially prevented by propranolol administration. $B$, Quantification of GluA1-IR in the molecular layer of lobule 5 from animals administered saline or propranolol before stress (naive, $N=5$; saline, $N=5$; propranolol, $N=5$ ). The level of GluA1-IR was significantly higher in the molecular layer in the propranolol-administered animals compared with the saline-injected mice. Scale bar, $100 \mu \mathrm{m} .{ }^{*} p<0.002$ (unpaired $t$ test).

A
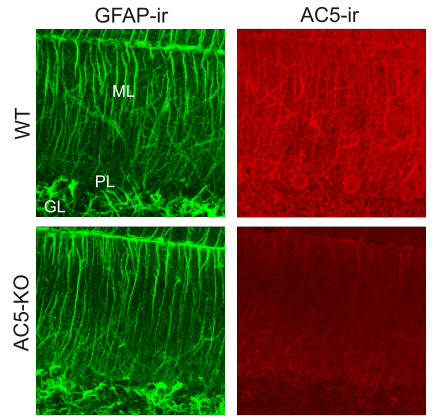
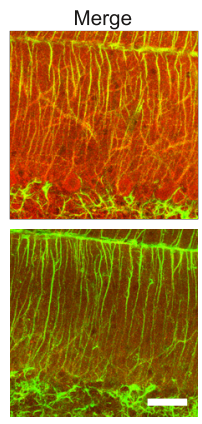

BG processes
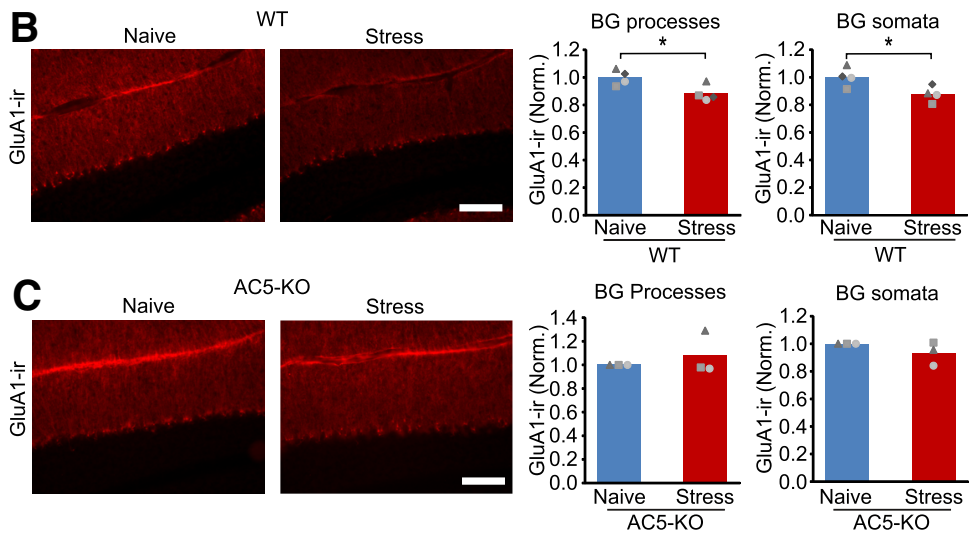

Figure 8. Adenylyl cyclase 5 mediates the stress-induced decrease in GluA1 expression. $\boldsymbol{A}$, Double staining for GFAP and AC5 indicates that $A C 5$ is expressed in the processes of Bergmann glial cells. AC5-IR was reduced in AC5 knock-out mice. $\boldsymbol{B}$, Epifluorescence images and the corresponding quantification of GluA1-IR in naive wild-type animals and after stress (BG processes: naive, $N=4$; stress, $N=4$ ). $C$, In contrast, $A C 5$ knock-out mice no longer showed any decrease in GluA1-IR after stress (naive $\mathrm{KO}, N=3$; stress $\mathrm{KO}, N=3$ ). $\mathrm{ML}$, Molecular layer; $\mathrm{GL}$, granule cell layer; $\mathrm{PL}$, Purkinje cell layer. Scale bars: $\boldsymbol{A}, 50 \mu \mathrm{m} ; \boldsymbol{B}$, C, $100 \mu \mathrm{m}$. ${ }^{*} p<0.04$ (unpaired $t$ test).

increase in AMPA receptor expression in hippocampal neurons, and impairs spatial memory formation and contextual fear learning (Pavlopoulos et al., 2011; Chao et al., 2013; Fioriti et al., 2015). Although CPEB3 is expressed at high levels in neurons, it is also present in astrocytes, including cerebellar Bergmann glial cells. Our finding that the deletion of CPEB3 prevented a stress-induced decrease in GluA1-IR and the amplitude of AMPAR currents suggests that $\mathrm{CPEB} 3$ is required for the reduction in GluA1 levels in Bergmann glial cells following acute emotional stress. These results can be explained by a simple model, in which a stress-induced binding of CPEB3 to GluA1 mRNA suppresses GluA1 synthesis in astrocytes.

A decrease in GluA1 protein expression level could result from reduced synthesis or/and accelerated degradation. While the GluA1 degradation rate in Bergmann glial cells has not been characterized, a study using HEK cells showed that in the presence of a protein synthesis inhibitor, GluAl expression decreased by $30 \%$ in $3 \mathrm{~h}$ (Huo et al., 2015), suggesting that GluA1 degradation can occur rapidly. Our finding that the deletion of CPEB3 prevented the reduction in GluA1 expression is consistent with a model in which stress suppresses GluA1 synthesis, such that protein degradation controls GluA1 levels, leading to GluA1 decrease. Stress may also enhance GluA1 degradation as shown following neuronal activity (Widagdo et al., 2015), but this remains to be tested.

In addition to Bergmann glial cells, CPEB3 is also expressed at a high level in the molecular layer interneurons (Fig. 5) and regulates synaptic GluA2 expression (Savtchouk et al., 2016). A number of CPEB3 targets have been identified, and thus the deletion of CPEB3 is likely to increase the expression of these target proteins, including the scaffolding protein PSD-95 and NMDA receptors, as shown in the hippocampal neurons (Chao et al., 2013; Huang et al., 2014). Since GluA1 expression in Bergmann glial cells can also be regulated indirectly by sonic hedgehog derived from Purkinje cells (Farmer et al., 2016), the deletion of CPEB3 in interneurons may alter neuron-astrocyte signaling and thereby regulate GluA1 expression in astrocytes. Our results show that the deletion of CPEB3 did not alter AMPA receptor-mediated currents and GluA1-IR relative to wild-type naive animals (Figs. $3,4)$. It is therefore unlikely that CPEB3 expression in interneurons is required to sustain the GluA1 level in Bergmann glial cells. It remains to be tested whether neuronal CPEB3 mediates neuron-astrocyte signaling during stress and triggers the decrease in GluA1 in Bergmann glial cells. 


\section{$\beta$-Adrenergic receptor-adenylyl cyclase 5 signaling pathways in astrocytes}

Astrocytes in the cerebellum and other brain regions express adrenergic (Porter and McCarthy, 1997) and glucocorticoid receptors (Porter and McCarthy, 1997), allowing them to directly respond to stress hormones. Noradrenaline in particular can modulate astrocyte structure and function, as $\beta$-adrenergic agonists increase the levels of cAMP in purified glial cells and induce rapid morphologic changes. Conversely $\alpha$-adrenoceptor antagonists inhibit the activation of astrocyte networks that are triggered by arousal and activation of the locus ceruleus (Rougon et al., 1983; Ding et al., 2013; Paukert et al., 2014; Vardjan et al., 2014).

Neurons in the locus ceruleus innervate the cerebellum, and noradrenaline release increases inhibitory interneuron activity and reduces Purkinje cell spiking (Siggins et al., 1971). We have previously shown that fox urine exposure induced a lasting change in GluA2 expression in cerebellar stellate cells via the activation of $\beta$-adrenergic receptors (Liu et al., 2010). Paukert et al. (2014) demonstrated a $\mathrm{Ca}^{2+}$ rise in cerebellar Bergmann glial cells on arousal, and this was mediated by adrenergic receptors. Together, these studies strongly suggest that predator odor stress can elevate noradrenaline levels and initiate noradrenergic signaling in cerebellar Bergmann glial cells. In this study, we identified a molecular cascade that orchestrates stress-induced astrocyte plasticity in the cerebellum. We show that the stressinduced decrease in GluA1-IR levels in Bergmann glial cells was partially prevented by prior administration of a $\beta$-adrenergic receptor antagonist. Therefore, the activation of adrenergic receptors during acute stress induces long-lasting astrocyte plasticity in the cerebellum. $\beta$-Adrenergic receptors are coupled to adenylyl cyclases, and genetic deletion of adenylyl cyclase subtypes shows that they are critically involved in anxiety-like behaviors (Krishnan et al., 2008). AC5 KO mice exhibit anxiolytic and antidepressant phenotypes in behavioral assays, and show a reduced stress-coping ability (Kim et al., 2008; Krishnan et al., 2008; Kim and Han, 2009). We found that Bergmann glial cells express AC5, and its deletion prevents the suppression of GluA1 levels following acute predator odor exposure. Thus, AC5-dependent astrocyte plasticity may contribute to the stress response and the change in behavior in $\mathrm{AC} 5 \mathrm{KO}$ mice. However, we cannot rule out the possibility that the presence of AC5 in cerebellar neurons may indirectly modulate GluA1 levels in Bergmann glial cells during stress. Because the knockdown of GluA1 in Bergmann glial cells reduces the length of fine processes, we propose that the regulation of GluAl expression is the molecular event that links a physiological stimulus to the subsequent structural remodeling of the astrocytic structure.

\section{Functional consequences of astrocyte plasticity}

The fine processes of Bergmann glial cells form close contacts with both excitatory and inhibitory synapses in the molecular layer of the cerebellar cortex (Ango et al., 2008). Because the glial glutamate transporter GLAST (glutamate aspartate transporter) clears glutamate after release (Chaudhry et al., 1995; Clark and Cull-Candy, 2002), a retraction of astrocyte fine processes could enhance glutamate transmission by removing glutamate transporters from the synapses. Bergmann glial cells also express GABA transporters (Barakat and Bordey, 2002), and thus the retraction of glial processes may also facilitate inhibitory transmission. Conversely, the neurotransmitters glutamate and GABA alter the activity of Bergmann glial cells via the activation of astrocytic AMPA and GABA receptors (Müller et al., 1994; Clark and Barbour, 1997). Since parallel fiber stimulation activates $\mathrm{Ca}^{2+}$-permeable GluA1-containing receptors in Bergmann glial cells, acute stress will reduce $\mathrm{Ca}^{2+}$ entry through AMPA receptors, which in turn can gate the release of glutamate from Bergmann glial cells (Cervetto et al., 2015). Therefore, stress may reduce the release of gliotransmitters and attenuate bidirectional signaling between neurons and glial cells.

The cerebellum is involved in motor coordination but has additional nonmotor functions, which are well documented in humans (Schmahmann et al., 2007). The best characterized cerebellar nonmotor role in rodents is the consolidation of fear memory and social interaction (Sacchetti et al., 2002; Carta et al., 2019). Fear conditioning selectively enhances excitatory and inhibitory synaptic transmission in lobule 5 , a lobule that is critically involved in fear memory consolidation (Sacchetti et al., 2002, 2004; Scelfo et al., 2008; Ruediger et al., 2011). Thus, the stress-induced retraction of glial process in cerebellar lobule 5 is likely to increase synaptic transmission and may serve as a mechanism for stress-enhanced memory consolidation (Bowers and Ressler, 2015; Perusini et al., 2016; Bender et al., 2018a,b).

Deletion of GluA1/GluA4 from all BG cells shows that their expression optimizes motor function (Saab et al., 2012). Because cerebellar vermal lobule $5 \mathrm{~B}-8 \mathrm{~B}$ receives input from the cerebral motor cortex, and is involved in controlling posture and locomotion in macaques (Coffman et al., 2011), the stress-induced reduction in GluA1 and the retraction of BG processes in lobule 5 may similarly influence motor coordination. For example, episodic ataxia type 1 results from increased GABA release onto Purkinje cells (Herson et al., 2003), and these episodes can be precipitated by emotional stress (Jen, 2000). A stress-induced remodeling of glial cell processes may enhance inhibitory transmission and contribute to motor deficits in episodic ataxia (Wulff et al., 2007).

AMPARs in Bergmann glial cells are known to control astrocyte structure, and we show that GluA1 expression can undergo an experience-dependent change. The activity-dependent regulation of GluA1 may serve as a common mechanism for structural remodeling of astrocytes in other brain regions as astrocytes in the olfactory bulb also express GluA1 and $\mathrm{Ca}^{2+}$-permeable AMPA receptors (Droste et al., 2017). Our findings that acute emotional stress regulates the expression of GluA1 via an adrenergic receptor/AC5/CPEB3 pathway reveal a novel mechanism underlying glial plasticity.

\section{References}

Ango F, Wu C, Van Der Want JJ, Wu P, Schachner M, Huang ZJ, Ghosh A (2008) Bergmann glia and the recognition molecule CHL1 organize GABAergic axons and direct innervation of Purkinje cell dendrites. PLoS Biol 6:739-756.

Araque A, Parpura V, Sanzgiri RP, Haydon PG (1999) Tripartite synapses: glia, the unacknowledged partner. Trends Neurosci 22:208-215.

Arganda-Carreras I, Fernández-González R, Muñoz-Barrutia A, Ortiz-DeSolorzano C (2010) 3D reconstruction of histological sections: application to mammary gland tissue. Microsc Res Tech 73:1019-1029.

Banasr M, Duman RS (2008) Glial loss in the prefrontal cortex is sufficient to induce depressive-like behaviors. Biol Psychiatry 64:863-870.

Barakat L, Bordey A (2002) GAT-1 and reversible GABA transport in Bergmann glia in slices. J Neurophysiol 88:1407-1419.

Baude A, Molnar E, Latawiec D, McIlhinney RAJ, Somogyi P (1994) Synaptic and nonsynaptic localization of the GluR1 subunit of the AMPA-type excitatory amino acid receptor in the rat cerebellum. J Neurosci 14:28302843.

Bender CL, Calfa GD, Molina VA (2016) Astrocyte plasticity induced by emotional stress: a new partner in psychiatric physiopathology? Prog Neuropsychopharmacol Biol Psychiatry 65:68-77. 
Bender CL, Giachero M, Comas-Mutis R, Molina VA, Calfa GD (2018a) Stress influences the dynamics of hippocampal structural remodeling associated with fear memory extinction. Neurobiol Learn Mem 155:412421.

Bender CL, Otamendi A, Calfa GD, Molina VA (2018b) Prior stress promotes the generalization of contextual fear memories: involvement of the GABAergic signaling within the basolateral amygdala complex. Prog Neuropsychopharmacol Biol Psychiatry 83:18-26.

Bostan AC, Dum RP, Strick PL (2013) Cerebellar networks with the cerebral cortex and basal ganglia. Trends Cogn Sci 17:241-254.

Bowers ME, Ressler KJ (2015) An overview of translationally informed treatments for posttraumatic stress disorder: animal models of Pavlovian fear conditioning to human clinical trials. Biol Psychiatry 78:E15-E27.

Carta I, Chen CH, Schott AL, Dorizan S, Khodakhah K (2019) Cerebellar modulation of the reward circuitry and social behavior. Science 363: eaav0581.

Cervetto C, Frattaroli D, Venturini A, Passalacqua M, Nobile M, Alloisio S, Tacchetti C, Maura G, Agnati LF, Marcoli M (2015) Calcium-permeable AMPA receptors trigger vesicular glutamate release from Bergmann gliosomes. Neuropharmacology 99:396-407.

Chao H-W, Tsai L-Y, Lu Y-L, Lin P-Y, Huang W-H, Chou H-J, Lu W-H, Lin H-C, Lee P-T, Huang Y-S (2013) Deletion of CPEB3 enhances hippocampus-dependent memory via increasing expressions of PSD95 and NMDA receptors. J Neurosci 33:17008-17022.

Chaudhry FA, Lehre KP, van Lookeren Campagne M, Ottersen OP, Danbolt NC, Storm-Mathisen J (1995) Glutamate transporters in glial plasma membranes: highly differentiated localizations revealed by quantitative ultrastructural immunocytochemistry. Neuron 15:711-720.

Christoffel DJ, Golden SA, Russo SJ (2011) Structural and synaptic plasticity in stress-related disorders. Rev Neurosci 22:535-549.

Clark BA, Barbour B (1997) Currents evoked in Bergmann glial cells by parallel fibre stimulation in rat cerebellar slices. J Physiol 502:335-350.

Clark BA, Cull-Candy SG (2002) Activity-dependent recruitment of extrasynaptic NMDA receptor activation at an AMPA receptor-only synapse. J Neurosci 22:4428-4436.

Coffman KA, Dum RP, Strick PL (2011) Cerebellar vermis is a target of projections from the motor areas in the cerebral cortex. Proc Natl Acad Sci U S A 108:16068-16073.

Davidson RJ, McEwen BS (2012) Social influences on neuroplasticity: stress and interventions to promote well-being. Nat Neurosci 15:689-695.

De Zeeuw CI, Hoogland TM (2015) Reappraisal of Bergmann glial cells as modulators of cerebellar circuit function. Front Cell Neurosci 9:246.

Ding F, O’Donnell J, Thrane AS, Zeppenfeld D, Kang H, Xie L, Wang F, Nedergaard M (2013) $\alpha 1$-Adrenergic receptors mediate coordinated $\mathrm{Ca} 2+$ signaling of cortical astrocytes in awake, behaving mice. Cell Calcium 54:387-394.

Drisaldi B, Colnaghi L, Fioriti L, Rao N, Myers C, Snyder AM, Metzger DJ, Tarasoff J, Konstantinov E, Fraser PE, Manley JL, Kandel ER (2015) SUMOylation is an inhibitory constraint that regulates the prion-like aggregation and activity of CPEB3. Cell Rep 11:1694-1702.

Droste D, Seifert G, Seddar L, Jädtke O, Steinhäuser C, Lohr C (2017) Ca $(2+)$-permeable AMPA receptors in mouse olfactory bulb astrocytes. Sci Rep 7:44817.

Edwards S, Baynes BB, Carmichael CY, Zamora-Martinez ER, Barrus M, Koob GF, Gilpin NW (2013) Traumatic stress reactivity promotes excessive alcohol drinking and alters the balance of prefrontal cortex-amygdala activity. Transl Psychiatry 3:e296.

Farmer WT, Abrahamsson T, Chierzi S, Lui C, Zaelzer C, Jones EV, Bally BP, Chen GG, Théroux JF, Peng J, Bourque CW, Charron F, Ernst C, Sjöström PJ, Murai KK (2016) Neurons diversify astrocytes in the adult brain through sonic hedgehog signaling. Science 351:849-854.

Fioriti L, Myers C, Huang Y-Y, Li X, Stephan JS, Trifilieff P, Colnaghi L, Kosmidis S, Drisaldi B, Pavlopoulos E, Kandel ER (2015) The persistence of hippocampal-based memory requires protein synthesis mediated by the prion-like protein CPEB3. Neuron 86:1433-1448.

Fischer H, Andersson JL, Furmark T, Fredrikson M (2000) Fear conditioning and brain activity: a positron emission tomography study in humans. Behav Neurosci 114:671-680

Franklin TB, Saab BJ, Mansuy IM (2012) Neural mechanisms of stress resilience and vulnerability. Neuron 75:747-761.
Herson PS, Virk M, Rustay NR, Bond CT, Crabbe JC, Adelman JP, Maylie J (2003) A mouse model of episodic ataxia type-1. Nat Neurosci 6:378383.

Hu H, Real E, Takamiya K, Kang M-G, Ledoux J, Huganir RL, Malinow R (2007) Emotion enhances learning via norepinephrine regulation of AMPA-receptor trafficking. Cell 131:160-173.

Huang WH, Chao HW, Tsai LY, Chung MH, Huang YS (2014) Elevated activation of CaMKII $\alpha$ in the CPEB3-knockout hippocampus impairs a specific form of NMDAR-dependent synaptic depotentiation. Front Cell Neurosci 8:367.

Huo Y, Khatri N, Hou Q, Gilbert J, Wang G, Man HY (2015) The deubiquitinating enzyme USP46 regulates AMPA receptor ubiquitination and trafficking. J Neurochem 134:1067-1080.

Iino M, Goto K, Kakegawa W, Okado H, Sudo M, Ishiuchi S, Miwa A, Takayasu Y, Saito I, Tsuzuki K, Ozawa S (2001) Glia-synapse interaction through $\mathrm{Ca} 2+$-permeable AMPA receptors in Bergmann glia. Science 292:926-929.

Jen J (2000) Familial episodic ataxias and related ion channel disorders. Curr Treat Options Neurol 2:429-431.

Kim K-S, Han P-L (2009) Mice lacking adenylyl cyclase-5 cope badly with repeated restraint stress. J Neurosci Res 87:2983-2993.

Kim K-S, Lee K-W, Baek I-S, Lim C-M, Krishnan V, Lee J-K, Nestler EJ, Han P-L (2008) Adenylyl cyclase-5 activity in the nucleus accumbens regulates anxiety-related behavior. J Neurochem 107:105-115

Kondo S, Marty A (1998) Differential effects of noradrenaline on evoked, spontaneous and miniature IPSCs in rat cerebellar stellate cells. J Physiol 509:233-243.

Krishnan V, Graham A, Mazei-Robison MS, Lagace DC, Kim K-S, Birnbaum S, Eisch AJ, Han P-L, Storm DR, Zachariou V, Nestler EJ (2008) Calcium-sensitive adenylyl cyclases in depression and anxiety: behavioral and biochemical consequences of isoform targeting. Biol Psychiatry 64:336-343.

Lee S, Song B, Kim J, Park K, Hong I, An B, Song S, Lee J, Park S, Kim J, Park D, Lee CJ, Kim K, Shin KS, Tsien RW, Choi S (2013) GluA1 phosphorylation at serine 831 in the lateral amygdala is required for fear renewal. Nat Neurosci 16:1436-1444.

Li C, Yang Y, Liu S, Fang H, Zhang Y, Furmanski O, Skinner J, Xing Y, Johns RA, Huganir RL, Tao F (2014) Stress induces pain transition by potentiation of AMPA receptor phosphorylation. J Neurosci 34:13737-13746.

Liu Y, Formisano L, Savtchouk I, Takayasu Y, Szabó G, Zukin RS, Liu SJ (2010) A single fear-inducing stimulus induces a transcription-dependent switch in synaptic AMPAR phenotype. Nat Neurosci 13:223-231.

McEwen BS, Gianaros PJ (2010) Central role of the brain in stress and adaptation: links to socioeconomic status, health, and disease. Ann N Y Acad Sci 1186:190-222.

Müller T, Fritschy JM, Grosche J, Pratt GD, Möhler H, Kettenmann H (1994) Developmental regulation of voltage-gated $\mathrm{K}^{+}$channel and $\mathrm{GABA}_{\mathrm{A}}$ receptor expression in Bergmann glial cells. J Neurosci 14:25032514.

Papp M, Gruca P, Lason-Tyburkiewicz M, Litwa E, Willner P (2014) Effects of chronic mild stress on the development of drug dependence in rats. Behav Pharmacol 25:518-531.

Paukert M, Agarwal A, Cha J, Doze VA, Kang JU, Bergles DE (2014) Norepinephrine controls astroglial responsiveness to local circuit activity. Neuron 82:1263-1270.

Pavlopoulos E, Trifilieff P, Chevaleyre V, Fioriti L, Zairis S, Pagano A, Malleret G, Kandel ER (2011) Neuralized1 activates CPEB3: a function for nonproteolytic ubiquitin in synaptic plasticity and memory storage. Cell 147:1369-1383.

Paxinos G, Franklin K (2001) The mouse brain in stereotaxic coordinates, Ed 2. San Diego: Academic

Perusini JN, Meyer EM, Long VA, Rau V, Nocera N, Avershal J, Maksymetz J, Spigelman I, Fanselow MS (2016) Induction and expression of fear sensitization caused by acute traumatic stress. Neuropsychopharmacology 41:45-57.

Petralia RS, Wenthold RJ (1992) Light and electron immunocytochemical localization of AMPA-selective glutamate receptors in the rat brain. J Comp Neurol 318:329-354.

Piet R, Jahr CE (2007) Glutamatergic and purinergic receptor-mediated calcium transients in Bergmann glial cells. J Neurosci 27:4027-4035.

Porter JT, McCarthy KD (1997) Astrocytic neurotransmitter receptors in situ and in vivo. Prog Neurobiol 51:439-455. 
Rougon G, Noble M, Mudge AW (1983) Neuropeptides modulate the betaadrenergic response of purified astrocytes in vitro. Nature 305:715-717.

Ruediger S, Vittori C, Bednarek E, Genoud C, Strata P, Sacchetti B, Caroni P (2011) Learning-related feedforward inhibitory connectivity growth required for memory precision. Nature 473:514-518.

Saab AS, Neumeyer A, Jahn HM, Cupido A, Sõimek AAM, Boele H-J, Scheller A, Le Meur K, Götz M, Monyer H, Sprengel R, Rubio ME, Deitmer JW, De Zeeuw CI, Kirchhoff F (2012) Bergmann glial AMPA receptors are required for fine motor coordination. Science 337:749-753.

Sacchetti B, Baldi E, Lorenzini CA, Bucherelli C (2002) Cerebellar role in fear-conditioning consolidation. Proc Natl Acad Sci U S A 99:84068411.

Sacchetti B, Scelfo B, Tempia F, Strata P (2004) Long-term synaptic changes induced in the cerebellar cortex by fear conditioning. Neuron 42:973982.

Savtchouk I, Liu SJ (2011) Remodeling of synaptic AMPA receptor subtype alters the probability and pattern of action potential firing. J Neurosci 31:501-511.

Savtchouk I, Sun L, Bender CL, Yang Q, Szabó G, Gasparini S, Liu SJ (2016) Topological regulation of synaptic AMPA receptor expression by the RNA-binding protein CPEB3. Cell Rep 17:86-103.

Scelfo B, Sacchetti B, Strata P (2008) Learning-related long-term potentiation of inhibitory synapses in the cerebellar cortex. Proc Natl Acad Sci U S A 105:769-774.

Schmahmann JD, Weilburg JB, Sherman JC (2007) The neuropsychiatry of the cerebellum - insights from the clinic. Cerebellum 6:254-267.

Shin LM, Liberzon I (2010) The neurocircuitry of fear, stress, and anxiety disorders. Neuropsychopharmacology 35:169-191.

Siggins GR, Hoffer BJ, Oliver AP, Bloom FE (1971) Activation of a central noradrenergic projection to cerebellum. Nature 233:481-483.

Staples LG (2010) Predator odor avoidance as a rodent model of anxiety: learning-mediated consequences beyond the initial exposure. Neurobiol Learn Mem 94:435-445.
Supple WF Jr, Leaton RN, Fanselow MS (1987) Effects of cerebellar vermal lesions on species-specific fear responses, neophobia, and taste-aversion learning in rats. Physiol Behav 39:579-586.

Takahashi LK, Nakashima BR, Hong H, Watanabe K (2005) The smell of danger: a behavioral and neural analysis of predator odor-induced fear. Neurosci Biobehav Rev 29:1157-1167.

Timmann D, Drepper J, Frings M, Maschke M, Richter S, Gerwig M, Kolb FP (2010) The human cerebellum contributes to motor, emotional and cognitive associative learning. A review. Cortex 46:845-857.

Tynan RJ, Beynon SB, Hinwood M, Johnson SJ, Nilsson M, Woods JJ, Walker FR (2013) Chronic stress-induced disruption of the astrocyte network is driven by structural atrophy and not loss of astrocytes. Acta Neuropathol 126:75-91.

Vardjan N, Kreft M, Zorec R (2014) Dynamics of $\beta$-adrenergic/cAMP signaling and morphological changes in cultured astrocytes. Glia 62:566-579.

Vialou V, Robison AJ, Laplant QC, Covington HE 3rd, Dietz DM, Ohnishi YN, Mouzon E, Rush AJ 3rd, Watts EL, Wallace DL, Iñiguez SD, Ohnishi YH, Steiner MA, Warren BL, Krishnan V, Bolaños CA, Neve RL, Ghose S, Berton O, Tamminga CA, et al. (2010) DeltaFosB in brain reward circuits mediates resilience to stress and antidepressant responses. Nat Neurosci 13:745-752.

Wang DO, Martin KC, Zukin RS (2010) Spatially restricting gene expression by local translation at synapses. Trends Neurosci 33:173-182.

Widagdo J, Chai YJ, Ridder MC, Chau YQ, Johnson RC, Sah P, Huganir RL, Anggono V (2015) Activity-dependent ubiquitination of GluAl and GluA2 regulates AMPA receptor intracellular sorting and degradation. Cell Rep 10:783-795.

Wulff P, Goetz T, Leppä E, Linden A-M, Renzi M, Swinny JD, Vekovischeva OY, Sieghart W, Somogyi P, Korpi ER, Farrant M, Wisden W (2007) From synapse to behavior: rapid modulation of defined neuronal types with engineered GABAA receptors. Nat Neurosci 10:923-929. 